\title{
Universities in Crisis? -New Challenges and Strategies in Two English City-regions
}

David Charles $^{\mathrm{a}, \mathrm{c}}$, Fumi Kitagawa ${ }^{\mathrm{b}}$, and Elvira Uyarra ${ }^{\mathrm{b}}$

${ }^{a}$ European Policies Research Centre, University of Strathclyde, 40 George Street, Glasgow, G1 1QE, UK, david.r.charles@strath.ac.uk

${ }^{b}$ Manchester Institute of Innovation Research, Manchester Business School, University of Manchester, Oxford Road, Manchester M13 9PL, UK, fumi.kitagawa@mbs.ac.uk;

elvira.uyarra@mbs.ac.uk

${ }^{c}$ Curtin Business School, Curtin University, Kent Street, Bentley WA 6102, Australia

\begin{abstract}
Universities in the UK have experienced dramatic changes since the onset of the global financial crisis, partly due to the immediate effects of the crisis, but also to the change in national government, upheavals in higher education (HE) policy and austerity measures. Increased pressure for local engagement with business has been combined with a rescaling of local economic development governance, and a shift from regional collaboration to a more localist agenda. This paper examines the implications of these changes on university institutional strategies and patterns of collaboration in two city regions: Newcastle and Greater Manchester.
\end{abstract}

Keywords: universities, city-regions, regional innovation systems, governance, regional development agencies, third mission

JEL Classifications: I23, O18, O33, R58 


\section{Introduction}

For over a decade, governments at regional, national, and European levels have been concerned with the role of universities in innovation (Mowery and Sampat, 2005), economic development and knowledge commercialisation (Geuna and Muscio, 2008), and wider engagement with knowledge users (Hughes, 2011). This development of a 'third' mission reflecting multiple forms of engagement (economic, social and cultural) (Trippl et al., 2012) has sat alongside a transformation from an elite model to a mass system of higher education (Scott, 2010), and a greater marketization as universities were expected to find new sources of funding. In the UK, universities have experienced an intensification of these changes since the onset of the global financial and economic crisis in 2008-2009, partly due to the immediate effects of the crisis, but more importantly arising from the change in national government in 2010, and subsequent upheavals in higher education policy in England, as a result of public austerity measures and the introduction of substantially higher tuition fees.

In this paper, we aim to illustrate some of the consequences of changes in the policy and institutional contexts that affect universities. In particular we focus on the shift in universities' roles in economic development from regional to city-region levels. The concept of 'city-regions' has gained popularity in both policy and theoretical discourses internationally over the last decade (e.g. Boudreau, 2003; Hall, 2009). In the UK, this has been accelerated by the new government policy landscape and 'scalar' shifts in England since 2010, with the abolition of the Regional Development Agencies (RDAs) and their replacement with smaller scale Local Enterprise Partnerships (LEPs) with lower levels of funding than those under the RDAs (Bentley and Pugalis, 2012). This scalar change has happened against the backdrop of the financial and economic 'crisis' (Hutton and Lee, 2012) which has not only been used as a justification for the policies of central government but also 
had other knock-on effects on universities through a shortage of private sector investment, changes in student behaviour and changes in demands and expectations from local stakeholders.

We examine the forces that underline the 'dynamic inter-relationships between policies, places and institutions' (Perry, 2011, p.246) regarding the regional roles of universities in the context of the spatial governance shifts over time. The culture and attitudes of institutions affect the ways in which they adjust to change or respond to challenge or opportunity (Rose et al., 2013). Historical, institutional and spatial processes can be better understood through examining specific case studies of organisations and their city-region contexts. The paper examines these intersections and conflicts through the framework of the 'engaged university' and the governance of local economic development, exemplifying their empirical outcomes through the case studies of two city-regions (Newcastle and Greater Manchester). Both of these two city-regions experienced considerable levels of collaboration between universities during the 2000s around economic and social development at both regional and city-region level, notably through regional science and innovation programmes (Warren et al., 2010), and Science City projects from 2005 (Charles and Wray, 2010, Perry, 2008). In both city-regions though there has subsequently been a rescaling of universities' engagement from the regional to the local level, and an emergence of new patterns of competitive institutional behaviour. In each of the city-regions studied, we analyse the factors that influenced universities' responses to changing policy and geographical contexts, considering different institutional types, capabilities, and resources. We also examine the evolution of the interactions and changing relationships between universities and other actors in the two city-regions. Hence, the key research question we ask in this paper is: How has policy since the crisis affected the 
spatiality of university engagement strategies and how has this affected the strategies for engagement of different types of university?

The rest of the paper is structured as follows. In Section 2, drawing on institutional theory, we identify academic and policy discourses as forces influencing institutional behaviour. We review the model of the 'engaged university', and the regional contribution of universities, exemplified by policy development in the UK over the last 15 years. In Section 3, we review the context of the current 'crisis' and the emergence of the 'city-regions' as a new strategic space for universities, with policy changes, including the new spatial governance structures of local economic development. Section 4 describes the methodology of our case studies, with the contexts of the two city-regions/regions. In Section 5, the two case studies are explored to examine the scalar shifts in engagement and the response to the crisis, and a final discussion draws out conclusions.

\section{From regional to urban knowledge governance: The 'engaged university' reconsidered}

The regional role of the university may be in part a contested issue (Power and Malmberg, 2008), and a variety of conceptual frameworks have been developed to explain and examine the nature of regional interactions involving universities. These alternative models have been reviewed in detail elsewhere (Uyarra, 2010) but have evolved from a narrow focus on universities as simple knowledge factories through entrepreneurial institutions and nodes within innovation systems. This study draws on the perspective of the 'engaged university' which refers to the commitment of universities to a broad range of activities (Lawton Smith, 2007) including 'civic engagement’ (Watson et al., 2013), 'public engagement' and 'community engagement' (Benneworth, 2013). It suggests a broader and more adaptive role performed by universities as 'enablers of regional development (OECD, 2007; Charles and Benneworth, 2001; Chatterton and Goddard 2000; Gunasekara, 2006; Breznitz and Feldman, 
2012), embedding a stronger regional focus in their missions (Glasson, 2003) within broadbased coalitions of state and non-state actors. This broader role includes the contribution of higher education to social, cultural and environmental development, by means of formal and informal participation and external representation as an institutional actor in regional networks of learning, innovation and governance (Boucher et al, 2003). The focus is shifted from knowledge transfer processes and systems to a greater focus on 'regional needs' (Uyarra, 2010). However universities are not simply bound within their regions but are complex institutions operating within multilevel policy frameworks - global, national and local (Marginson, 2004) - and as such seek to join up and integrate across missions and across spatial scales (Charles, 2006). Universities take on responsibilities as 'stewards of place’ (AASCU, 2002), as partners in local governance, but bringing knowledge and resources from other spatial scales (Arbo and Benneworth, 2006).

These models of the engaged university have been disseminated through various funding mechanisms resulting in 'formal/regulative, normative and cognitive' forces, underlining high policy expectations, and influencing institutional missions and strategies - arguably leading to a process of institutional isomorphism (see DiMaggio and Powell 1983). Formal and regulative forces such as government funding streams steer university behaviour. Normative policy discourses and institutional models are created at national, sub-national, and international levels, and disseminated by national policy instruments as 'good practices' and 'benchmarking exercises', and by inter-governmental bodies such as the OECD (e.g. OECD 1999; 2007). Cognitive transformation takes place within institutions, affecting institutional behaviour: through incentives, recognition and reward mechanisms; or through informal changes of culture and individual behaviour. 
At the same time, the differentiation of mechanisms at the institutional level is strengthened by policy initiatives, and funding. Within national and regional systems of innovation and higher education (Mowery and Sampat, 2005; Uyarra, 2010), different types of universities have been encouraged to work together, and a greater differentiation of roles has been encouraged, with complementarities in their resources, knowledge and competences (OECD, 2007). Arguably, universities with different organisational heritage play different roles, reflecting institutional priorities, cultures and governance structures, and also a different mix of discipline areas and the nature of work of individual academics (Perkmann et al., 2011; Abreu and Grinevich, 2013; Hewitt-Dundas, 2012). In the UK, for example, a clear hierarchy exists between the older research intensive civic universities (Russell Group), more recent research universities of the 1960s (often in smaller cities), and the 'new' universities, originally established as polytechnics and colleges under local authority control, but converted to university status since 1992. There is an assumption that the latter are more 'locally oriented' given their traditional focus on vocational education and training, combined with lower levels of activity and funding in basic research.

Such institutional diversity could be viewed as providing the opportunity to meet the "needs of specific regional and local economic and social contexts” (Little and Williams, 2009; p.6). However, the diversity of university types has not been sufficiently recognised by scholars or policy makers (Huggins et al., 2012). Recent work has also begun to question the high level of policy expectations, with little understanding of the actual processes of knowledge flows, the contextualisation of the complexities of actors, and the extent to which regional economic or city-region development can be actually achieved through the utilization of university knowledge (see, Benneworth et al., 2010; Power and Malmberg, 2008; Huggins et al. 2012). 
Questions have been raised about whether the 'regional' level really provides optimal institutional relationships for universities, businesses and other actors, and recent studies have begun to emphasise new configurations of networks and alliances, which are inter-and intraregional and urban. More recently, the ‘city-university relationship’ (Williams et al., 2008) or 'the roles of universities in knowledge based urban development' (Charles, 2011) has attracted growing policy attention as the concept of 'city-regions' and the new urban entrepreneurialism (Turok, 2009; Etherington and Jones, 2009) gained popularity in both policy and theoretical discourses (see Perry, 2008; 2011; Goddard and Vallance, 2013; Stachowiak et al. 2013). The 'city- university relationship' is seen as pivotal to the economy by helping places "adapt to changes in the wider economy, increase the proportion of knowledge intensive jobs and workers, and deliver beneficial outcomes for communities” (Williams et al., 2008, p. 4). However, it is also recognised that implementation is not straightforward, and difficulties exist in finding a balance between the expectations and agendas of various stakeholders.

The 'engaged university' model needs to be examined in light of these complex and changing spatial, institutional, relational and situational contexts. The next section examines the context of such spatial governance shifts as observed in England in the current crisis.

\section{Spatial Governance Shifts, Crisis and Institutional changes in English city regions}

In the UK, since the late 1990s, universities as 'sources and repositories of knowledge' (Lambert 2003) have been given a central role in the delivery of public policies designed to drive economic and social development in the knowledge economy, especially in line with local and regional economic agendas (Trippl et al., 2012), whilst certain types of institutions have stronger roots in their regions than others. A shift in spatial governance for UK universities began under the 1997-2010 New Labour government, following the 
recommendations of the Dearing Report on higher education (NCIHE, 1997). Prior to this point only tentative attempts had been made by government to encourage university engagement and regional collaboration.

New Labour introduced a stronger regional emphasis in both economic development and in HE policy. Whilst the previous government had brought together the regional branches of central government departments into new integrated Government Offices, in 1999 Labour introduced regional development agencies (RDAs) in the nine English regions, as nondepartmental public bodies with considerable budgets (£200-300 million p.a. in the case of the North East and North West). The RDAs had wide powers to support economic development in their regions, from innovation to industrial land supply.

The economic and social contributions of universities were seen to be public goods, supported both by regional bodies (e.g. the RDAs and Regional Government Offices) and by higher education funding bodies through the so-called 'third stream' funding such as the Higher Education Innovation Fund (HEIF) available in England. In England, regional associations of higher education institutions (HEIs) were part-funded by the Higher Education Funding Council for England (HEFCE) to promote the role of HEIs in each region at the time the RDAs were established. The associations placed a particular emphasis on fostering collaboration between HEIs, and building partnerships with other organisations within their regions (Kitagawa, 2004). This was paralleled by the development of regional science policies, initially in the North West and North East regions, with industry and innovation strategies and support mechanisms developed along with HEIs (Perry, 2007; Uyarra and Flanagan, 2010). Under the ‘engaged university’ model, universities were incentivised with a number of public funding schemes to collaborate at the regional level, to 
promote 'regional innovation', enhance regional 'well-being' and meet 'regional needs' (Goddard and Chatterton, 1999).

Until the mid-2000s, the role of “cities” in science and innovation policy was largely absent, At best regional and local were seen as synonymous, without due consideration of the potential active role of local partners in delivering on government objectives (Perry, 2008). This situation changed with the designation of six Science Cities (Manchester, York, and Newcastle in 2004 and Bristol, Birmingham, and Nottingham in 2005), the aim being to use their strong research base to drive city-regional growth by strengthening linkages between business, the public sector and the science community; accelerating the process through which ideas and discoveries were commercialised; and increasing the visibility of these cities to attract talent and investment (HMT, DTI, DES, 2004; Charles and Wray, 2010).

Whilst the designation of science cities was a national initiative, each city had to develop its own steering group and strategy. This localist approach was presented by the government as deliberate: "we should not seek to have a national plan for science cities or dictate what individual areas do” (Sainsbury, 2007). In some regions the science cities exposed tensions between the top down regional strategies and more local alliances between universities and their immediate communities (Perry, 2011). Regional science and innovation strategies began to take on a more nuanced spatial character to reflect the need to connect with science cities and with the ambitions of other city-regions not designated as such.

Whilst science cities were emerging at the sub-regional level with local innovation agendas, there was a parallel cross-regional initiative involving universities in three northern RDA regions. The N8 Research Partnership was set up in 2007, bringing together eight researchintensive universities to collaborate in strategic research areas and work with industry. ${ }^{\mathrm{i}}$ 
The financial crisis that hit the global economy in the autumn of 2007 strongly affected the UK economy and the higher education sector. The subsequent changes in the English higher education sector also brought into sharp relief the internal divisions in the UK, with England following a different path from Scotland on tuition fees, with Wales and Northern Ireland somewhere in between. Thus whilst a recognition of the importance of universities to economic development and knowledge commercialisation persists across the whole of the UK, the effects of specific policy changes are playing out differently across the country with the devolution processes (see Universities UK, 2008), which had preceded the economic crisis. Since the crisis, economic as well as social engagement activities have made universities, in principle, a more integrated part of the institutional fabric of the city-region (see Kitson et al., 2009). The economic development landscape was also changing as the Coalition government announced in October 2010 (DBIS, 2010) the abolition of the nine RDAs in England and their replacement with Local Enterprise Partnerships (LEPs) at a cityregion level. The government's approach to the governance of local economic development, including "City Deals" and "Localism”, raises a series of questions about the autonomy of the local authorities in relation to central government related to accountability, efficiency and innovation (Bentley and Pugalis, 2012).

LEPs are partnerships between local authorities and businesses and are expected to play a key role in promoting local economic development. Half the LEP board members were to be drawn from industry/local commerce and led by a local business leader. LEPs however are much constrained in terms of economic resources compared to the RDAs, although they are able to bid for funds from a new Regional Growth Fund (RGF). One might argue that LEPs do not have sufficient powers to create the private sector jobs growth needed for the cityregions to recover from recession. Concerns have been expressed about competition between LEPs, as well as sustainable economic growth in less-favoured regions with scarce public 
support for local economic development. The overall agenda represents a significant scalar shift in local economic development with an emerging vacuum at the regional level, and the “re-centralisation of many economic development functions" as many functions, including inward investment, SME support and development, sector and cluster policy will be "passed back to" the national level, if not abolished completely (Bentley et al., 2010). Additionally there is the emergence of new urban governance institutions and structures. Thus the subnational governance 'system' has suffered a multi-dimensional and multi-scalar 'shock' (Kitagawa, 2012), and city-regions need to respond to these changes by aligning with new actors, in order to mobilise resources.

Universities also need to find a new set of institutional strategies and a set of practices to meet the demands and opportunities at local as well as national and global levels (Perry, 2008). A recent independent review conducted by Sir Andrew Witty for the government on "universities and growth” emphasises the heterogeneity of both universities and LEPs (and LEP strategies), and of the LEP areas. It is argued that these differing circumstances will need different models of university-LEP interaction (DBIS, 2013). This has coincided with the growing pressure for universities to respond to the research 'impact' agenda promoted by the higher education funding councils and the research councils (Martin, 2012). There has also been a drastic reduction by the government of teaching funding for English HEIs, following the recommendations of the Browne (2010) review, with a substantial raising of the cap on tuition fees and further changes in the allocation of student places since 2012. This has led to a growing need for universities to demonstrate the value of education to individual students (and their families) and prospective employers. Universities are increasingly expected to demonstrate the relevance of research activities, and produce graduates with the skills required by employers in various industrial as well as public and third sectors. 


\section{Going beyond the crisis? - Case studies of universities in the two city-regions}

\section{Methodology}

The empirical study draws on qualitative case studies in order to illustrate the institutional specificity of the perceived 'crisis', the geographical contexts and positioning of institutions, and individual stakeholders' perceptions of changes in policy, opportunities and challenges in specific city-regional contexts. The two case studies have been developed on the basis of long term engagement of the authors in each of the regions, drawing on documentation, interviews over a period of several years and in some cases participant observation. Additional semistructured interviews were undertaken in 2012 to provide information about the current regional strategies pursued by the universities and their relationship with regional and local development bodies and funds. This included interviews with senior staff of universities with involvement for engagement (such as pro vice-chancellors (PVCs) or heads of engagement offices) as well as those responsible for research and broader institutional strategies in order to situate the local and regional engagement within the wider context. Interviews were also conducted with senior staff from the former RDAs and Government Offices, local authorities and other regional partners. Between 10 and 12 interviews were undertaken in each city regionii throughout 2012. Whilst these interviews are limited in terms of the scope and generalisability, following the recent work by Rose et al., (2013, p.260) we reflect the interviews as 'moments in history', that provide 'fleeting snapshots of perceptions at a particular point in time', which are shaped by past shared experiences, challenges and opportunities. The historical context presented in this paper is also shaped by a large number of previous interviews and meetings, including a previous ESRC-funded project on regional science strategies. Quantitative data are presented using secondary data available through the 
Higher Education Statistics Agency (HESA) such as the HE Business and Community Interaction (HEBCI) Survey.

The case study regions - the North East and the North West

Manchester and Newcastle are two old industrial cities situated in the North of England, in regions which have under-performed in economic terms relative to the UK average in recent decades. Manchester and the North West region are larger than Newcastle and the North East and have a stronger economy, although both regions lag the national economy (see table 1). Both traditionally manufacturing regions, in the last 20 years they have diversified into higher technology industries, but manufacturing still accounts for $20 \%$ of North West GDP. In both regions the overwhelming shift has been towards services, with public services being an important component in the North East. Accordingly both Newcastle and Manchester have experienced something of an urban renaissance although still with significant pockets of deprivation (Goddard and Vallance, 2013; Uyarra and Flanagan, 2010). The two cities form the core of two city-regions, each made up of the former metropolitan counties - Greater Manchester and Tyne and Wear, but also with a strong functional relationship with other districts.

Table 1 near here

The North East has five universities: Newcastle, Durham, Northumbria, Sunderland and Teesside, of which the first four all lie within the Newcastle city region. Newcastle and Durham are old research-intensive universities. Newcastle is the slightly larger of the two, based on a single campus in the centre of Newcastle, whilst Durham is a collegiate university 
based in the city of Durham but also with a campus at Stockton on Teesside. The other three universities were originally polytechnics, converted to universities in 1992, and are located at the heart of Newcastle, Sunderland and Middlesbrough respectively. All five universities are fairly large by UK standards, together providing over 80,000 student places, with the North East being a net importer of students.

The North East was the first of the English regions to discover regionalism in higher education, setting up a voluntary association in 1983 to support local industry in the wake of the early 1980s recession, drawing on EU assistance for training activities in the late 1980s. This body, Higher Education Support for Industry in the North (HESIN), brought together all five HEIs in the region, and was intended to stimulate collaborative training and technology transfer activities to assist local industry, and established a joint engineering masters programme.

The North West as a bigger region has 12 universities of which four are within the Manchester City region: Manchester, Manchester Metropolitan, Salford and Bolton. Manchester is one of the largest research intensive universities in the country and was formed from the merger of the former Victoria University of Manchester and UMIST in 2004. Manchester Metropolitan University (MMU) was the former polytechnic, Salford is a smaller university created in the 1960s from a technology institute, and Bolton is relatively recent university established in 2005. Elsewhere in the region there is a cluster of four universities in the Liverpool area, plus universities in Chester, Lancaster, Central Lancashire and Cumbria. The combined turnover of the higher education institutions (HEIs) of the region is estimated at over $£ 1.3$ bn with an overall economic impact to the North West regional economy in excess of £3bn. The institutions employ more than 36,000 people (of which 56\% are employed in knowledge based academic, managerial or professorial positions, NWUA, 2010) 
and there are at least 200,000 HE students. It is estimated that nearly 10,000 jobs are created in the region as a result of the knock-on benefits of HE activity (NWUA, 2010).

\section{Regionalisation and HE in the 1990s to 2000s}

During the 1990s and 2000s, the two case study regions witnessed a series of moments and 'turns', in the regional and local roles of higher education institutions (HEIs), with different forms of collaborations emerging.

In the North East region, in the 1990s the EU Structural Funds ${ }^{\text {iii }}$ offered the main opportunity for universities to access funding for engagement with business. The programmes, post 1994, were designed at a regional level to cover the whole North East, and whilst there were subregional elements focused mainly on regeneration, the innovation measures were largely coordinated at a regional scale, and the managers of the schemes in the Government Office were particularly keen to see the universities' involvement through regional scale collaborative projects. With European Regional Development Fund (ERDF) support, HESIN made significant progress, notably with the establishment of the Knowledge House programme in 1996. This network, involving all the universities, was a one-stop-shop to help SMEs find expertise within the universities (Potts, 1998). This project operated from 1996 through to 2008 extremely successfully with a combination of ERDF and later HEIF support. Other projects focused on developing consortia to support particular industries in the region, again largely with ERDF support initially. This thus reinforced the development of HESIN in the run-up to the establishment of RDAs by the Labour government of 1997. In 2000 the association was renamed Universities for the North East (UNE) to recognise its expanded scope beyond support for industry. Project income enabled the development of a substantial team in UNE and by the 2011 it had project managed a cumulative $£ 68$ million of grant 
income and $£ 33$ million of private sector income to the member universities (information provided by UNE in 2012).

This movement towards a regional perspective never excluded a parallel local orientation and Teesside and Sunderland universities in particular maintained a strong local orientation in their engagement, whilst Newcastle followed a regional approach, as did Durham, especially with its campus on Teesside and a relatively low absorptive capacity in Durham itself.

In the North West, while earlier institutional collaborations between HEIs under the European Structural Funds happened within the region, the region-wide collaborative mechanism was not so prominent until the formation of the North West Universities Association (NWUA) in the late 1990s. NWUA was formed in 1999 along with the RDA, the North West Development Agency (NWDA). NWUA represented 12 HEIs in the region and coordinated regional activities to identify opportunities for collaborative actions, including bidding and managing European Structural Fund and HEFCE funded projects, developing partnerships with industry and public bodies for the economic, social and cultural well-being of the region (see Briggs, 2013). In the 2000-2006 programme, North West universities were allocated over $£ 138$ million ERDF and European Social Fund (ESF) funding. With matchfunding, this represented an HE sector investment of approximately £228 million (NWUA, 2010).

In the North West region, the Greater Manchester city-region had developed its own HE mechanisms which coexisted with the NWUA. Alongside the NWUA, the CONTACT partnership of the four universities in Greater Manchester (Salford, MMU, UMIST and the Victoria University of Manchester, then) was created in 2000. In 2004 it secured £0.5m funding from HEIF 2 to undertake a series of third stream activities, which was match-funded by the NWDA and supported with additional resources by the partner universities. Another 
city-regional university partnership the Manchester Knowledge Capital initiative (M:KC) was created in 2003. Both CONTACT partnership and M:KC aimed to "positively impact the city regional economy - and demonstrate the cities' HEI’s collective commitment to Greater Manchester's on-going growth and success” (CONTACT, 2008). This early development of distinctive collaborative mechanisms including three or four universities and their partners at the city-region level was unique to Greater Manchester.

The North West and North East regions were the first two regions in England that developed regional science strategies (Perry, 2007; Uyarra and Flanagan, 2010; Charles 2008). One North East (ONE), the RDA in the North East, used this to identify five primary science based themes for new centres of excellence: new and renewable energy, process industries, life sciences, information and communication technologies, and nanotechnology. These centres of excellence were to be new intermediaries, outside of the HE sector, in some senses competing with the universities but with joint projects and some investments in the universities. Additional funding went into some university research infrastructures. While ONE made a conscious decision to develop Centres of Excellence separate from universities, the NWDA decided to make direct investment in universities, in particular by supporting universities R\&D centres to reach-out to industry, supported by HEIF money (Charles, 2008; Goddard et al 2012). This is arguably seen as a more science-oriented approach in its regional innovation strategy (OECD, 2008), aligning regional needs with R\&D activities in universities.

\section{Emergence of Science Cities}

The importance of the regional scale as a level of strategy making started to lose momentum in the mid-2000s. The failure of the North East referendum for an elected regional assembly 
meant that greater devolution was off the policy agenda and, at the same time, metropolitan areas were increasingly seen as key loci of economic development.

The perception that RDAs were placing insufficient focus on the role of cities gave momentum to pre-existing views supporting the creation of conurbation-wide structures of governance (Deas and Ward, 2002). All this also informed the Core Cities group, seeking to lobby central government on behalf of England's eight largest cities outside London about the role of cities in driving economic growth and the need to promote policies to enhance their competitiveness. The national designation of Science Cities from 2004, including both Manchester and Newcastle built on these foundations (see Charles and Wray, 2010).

Manchester’s Science City project was incorporated into the Manchester Knowledge Capital (M:KC) project (see above). The M:KC was a strategic partnership of Greater Manchester universities, local authorities, regional government, businesses, NHS and key local agencies. M:KC sought to bring partners together, and catalyse the development of innovation ideas and providing capacity for a series of profile-raising projects and funding bids for Greater Manchester. The merger of the Victoria University of Manchester and UMIST in 2004 had resulted in greater alignment of the two universities with the city council and in pursuit of the city region agenda. Supported by a strong synergy and consensus, the Manchester Knowledge Capital's vision was of “a 'Northern Hub of economic, social and cultural activity” (M:KC 2003; p.30). Compared to other science cities, this vision was "altogether bolder, more wideranging and ambitious in scale and scope” (Perry, 2008,p. 32).

In Newcastle the science city project had no precursor, and the announcement led to Newcastle University, the City Council and RDA working together to develop a strategy. The RDA was keen to have Durham also involved, especially in view of Durham's strength in science and its existing involvement in the RDA-backed Stem Cell Institute in Newcastle, 
although Durham was less enthusiastic in being involved in something based so much in Newcastle. The initiative quickly became associated with a major property development known as Science Central. However there were many other activities associated with Newcastle Science City especially promotion of science in schools and community outreach.

The Science City initiative introduced a place dimension to the North East science and innovation strategy, with other parts of the region looking to develop their own more focused initiatives, connecting innovation to sites for physical regeneration and/or enterprise. This 'innovation connector’ programme complemented centres of excellence and gave the other regional universities local projects to work with - Teesside Digital City, Sunderland Software City, and NETPark near Durham. Northumbria University was excluded from much of the discussion around Newcastle Science City as its contribution to the science base was deemed to be limited, but it was seen as a key player in an alternative project focused on design, to be located in Gateshead. So by 2008 the RDA was pushing a strong sub-regional dimension to its science and innovation strategy with universities working at both regional and local levels in strategic projects.

\section{Crisis, austerity and replacement of regionalism with new localism}

While the global financial crisis in 2007 hit the North East early through the collapse and government takeover of its local bank Northern Rock (Dawley et al., 2012), both North East and North West regions were quickly caught up in concerns about shortages of capital for local business and the drop in consumer demand.

Some universities responded to the immediate problems of the firms in the economic downturn in their region and city-regions. For example, Newcastle and Durham Universities in the North East established the Angel Alliance with ONE in 2008 to identify areas of 
science where there was mutual benefit in collaboration and exploitation, with the aim of benefit to the wider region. At the beginning of 2009 Newcastle launched its 'ten steps to help boost the economy’. This included a greater focus on procurement from local suppliers, the bringing forward of major capital and energy-saving investments, a business voucher scheme, subsidised training, faster payments for local suppliers, expansion of student work experience schemes and an expansion of free or low cost cultural events for families. In the North West region, nine universities were successful in securing funding from the $£ 27.6$ million national HEFCE Economic Challenge Investment Fund (ECIF) to counter the impact of economic downturn on individuals and employers in their region (NWUA, 2010).

The onset of the economic crisis came at a time when regional connections were already starting to break down in the two regions, accelerated through the gradual rise of localism under New Labour. With the defeat of Labour and the formation of a coalition government between Conservatives and Liberal Democrats in May 2010, the environment for universities in the two regions shifted further from regionalism. The abolition of the RDAs and replacement with LEPs, accentuated the tensions between universities and the regional governance structures. The financial crisis and the economic downturn, followed by the major changes in the higher education funding schemes, especially the new tuition fees in England introduced in the autumn of 2012, seem to have further conditioned the ways universities engage with their city-regions. In order to illustrate these on-going changes and responses to the crisis, in the rest of this section, we focus on institutional changes within the two city-regions.

In Greater Manchester, the introduction of the new LEP reinforced the existing political boundary. The 10 local authorities in Greater Manchester had formed the Association of Greater Manchester Authorities (AGMA) in 1986, and worked closely prior to the formation 
of the LEP in 2012. For instance, AGMA had created the Commission for New Economy in 2009, an economic intelligence body for Greater Manchester with a lead role in implementing the economic priorities of the Greater Manchester Strategy. The LEP in Manchester was blended into existing governance structures.

In the North East the movement to a LEP covering Newcastle city regions was more difficult. In the south of the region the five unitary Tees Valley local authorities had already a merged economic development function that operated as a sub-regional partnership with ONE. This migrated smoothly to LEP status, with the advantage of a large staff. Teesside University built a close working relationship with the LEP, with their vice-chancellor as a board member. This left the rest of the North East to try to form a LEP almost by default. With most of Durham and Northumberland tied functionally into the Newcastle city-region, anything other than a single LEP would make little sense, but the internal tensions of a single North East LEP slowed its development, not least over the arguments about sites for an enterprise zone, with an 'anywhere but Newcastle’ principle dominating (Shaw and Robinson, 2012; Newcastle Journal, 2011).

\section{Post-crisis institutional strategies}

The financial crisis and the following austerity measures affected the availability of private and public funding for universities in the areas of knowledge exchange and external engagement. The North East and North West saw a reduction in income from knowledge exchange of $6 \%$ and $5 \%$ respectively (excluding income from RDA programmes) between the periods 2010-2011 and 2011-2012, while on aggregate universities in other regions have maintained or increased their income from knowledge exchange (HESA, 2013). Companies cut their R\&D budgets, which halted in the growth of contract income for universities. As the funding from the RDAs decreased before their closure, public investment for Science City 
projects dried up and support for spin-offs shrank. In the North East of England income from SMEs decreased by 22\% from 2010-2011 levels (HESA, 2013). Naturally, low and medium research intensive universities mainly serving a local and regional SME and public sector customer base have exhibited the greatest decrease in income (HESA, 2013). The picture at the city-regional level is more complex as different types of institutions and different types of activities have to be taken into account.

The major changes are observed and presented at three levels:

- changes in strategic directions for individual institutions including strategies for knowledge exchange, tuition fees, student enterprise, research impact, and physical campus development;

- changes in income sources for knowledge exchange activities across time; and

- changes in collaborative relationships which universities had developed over the previous decade at regional and city-region levels.

All universities make contributions to their immediate locality, but the extent and configuration of the territory over which that contribution is made varies by institution and even within the institution between activities and over time. These contributions include physical infrastructure, human capital (education), interactions with public bodies, research commercialisation and public engagement. Furthermore, geographical choices are conditioned by the institutional strategies and priorities of each university (Charles, 2003). Institutions make choices about the scope of their primary geographical locality in terms of their mission, often specifying some form of locality. In some cases this is historically based, but it can also be affected by external policy drivers or the particular engagement strategy adopted by the university. During the 2000s it was typical for universities to adopt a regional 
perspective, driven by national policies (Charles, 2003) as identified by a question in the annual HEBCI survey on the area of greatest priority in the institutional mission (table 2). Of the eight HEIs in the two city-regions, six identified with the RDA area in 2007 as being of greatest significance, a number which had fallen to 3 by 2011. More universities are identifying with an area of their own designation, implying an area not defined by the boundaries of a tier of government, in most cases some form of city-region area.

Table 2 near here

All universities in England were required to submit institutional strategies for 2011-2015 relating to their HEIF activities to HEFCE in July 2011 (HEFCE 2011). Among the eight universities studied, all except Durham mention their contribution to the regions and cityregions as part of their institutional missions and their knowledge exchange strategies. Durham shifted their knowledge exchange strategy away from regional engagement to an international strategy in support of research and education, given the "demise of regional organisations and their associated funding streams”.

The key perception of the universities of the current environment seems to be "increased competition for funding” in general, as well as in the city-region contexts. All the eight universities in the two city-regions raised concerns about the decline in funding from public sources, especially due to the closure of the RDAs, "tight fiscal constraints surrounding local authorities" and "strong competition for other public sources” such as ERDF. Newcastle University specifically states "reduction in regional resources dedicated to innovation" and changes to regional policy as a barrier for knowledge exchange. Northumbria sees potential 
challenges in their Continuing Professional Development (CPD) provision as investment from the NHS and local governments is to decrease in the current economic climate and greater competition is expected between HEIs and other providers.

The dramatic increase in student fees, and introduction of more quasi market mechanisms for recruiting students has sharpened universities’ thinking about perceived risk. With considerable financial risk from any shortfall in recruitment, universities perceive a need to be risk averse in other areas such as external engagement. Investment is needed to enhance the teaching and learning infrastructure, student retention and satisfaction, which in some cases has diverted effort from other parts of the mission, which may "suppress knowledge exchange activity in the short term” (University of Sunderland, 2012). Even student enterprise, whilst still seen positively by many of the universities in terms of employability and entrepreneurial skills development, may be an area for concern as students are acquiring much higher levels of debt and may themselves be more risk averse in the future.

Despite this there remains pressure for knowledge exchange from the Research Excellence Framework (REF), as reported both by research intensive and less research intensive universities in the two city-regions in the HEIF strategies. Salford states that the KE agenda has raised profile and support in the university governance structure. Manchester, MMU, Salford and Northumbria state in their HEIF strategies 2011-15 that they have changed or developed reward and promotion criteria to include knowledge exchange activities.

All the eight universities are embedded in various forms of sub-regional local partnerships including the highest leadership level. While the Vice Chancellors of Manchester and Newcastle Universities represent the higher education sector on their respective LEP boards, other universities play strategic roles with individual local authorities and sub-regional partnerships, and influencing their strategies (e.g. Sunderland Masterplan), and relationships 
with the NHS and other public organisations are presented as important areas of strategic partnerships for the institutions.

Some universities (e.g. Teesside, Newcastle and Bolton) received Economic Challenge Investment Fund (ECIF) from HEFCE, which was intended to support individuals and employers tackling the impact of the economic downturn. Universities have also supported the local economy through financial crisis and economic downturn through the development of physical infrastructure and regeneration, often working with local authorities as well as the private sector. Some of the case study universities had large campus development schemes which were on site during the early years of the recession. In Newcastle's case this included a large number of new teaching and research facilities on campus (estimated at around £200 million in value), and some of this work on energy efficiency measures, landscaping and campus enhancement was brought forward explicitly to help support local construction firms. Manchester University also was in the middle of a $£ 600$ million capital programme following the merger, and a number of other university redevelopment schemes underpinned construction jobs through the depths of the recession. Salford University had been developing its new campus, opened in 2011, as part of MediaCityUK, along with BBC and Granada. Manchester Metropolitan University opened a new business school with a £200 million capital investment and is going to open the $£ 139$ million new community campus at the Birley Fields site in inner city Manchester in the summer of 2014.

The institutional strategies and the on-going engagement activities need to be set against the reality of changing resources available to the universities. All the universities had been able to access various sources of funding, including ERDF and RDA funds, but with varying proportions over time (Figures 1 and 2). Other regeneration funding included a variety of national local government programmes, and was relatively more important in Manchester 
than in Newcastle. What is notable however is that funding has been falling since 2004, partly due to an early reduction in ERDF funding, as universities have perhaps reduced their exposure to risks of clawback associated with the ERDF. One of the universities had experienced a considerable financial loss as a result of having to pay back ERDF grant when a project failed to meet its targets and that experience has made all universities more cautious. Obviously RDA funding has also reduced, although the North East RDA put more funding into its universities over a longer period of time than the North West. Overall levels of regeneration funding were higher in the Newcastle city-region than in Greater Manchester.

Figures 1 and 2 near here

Looking at the total level of income for each of the eight universities from all regeneration sources and from RDAs (figures 3 and 4), Newcastle University was the principal outlier with a very marked peak in funding around 2007, partly due to RDA income but also ERDF, both related to investments in stem cells and science city initiatives. Salford also has been highly successful with both ERDF and national government regeneration funds.

Figures 3 and 4 near here

From 2007 onwards grants from the RDAs to universities had already started to decline from what had been higher levels in the early 2000s when large capital projects were more common. Newcastle, Sunderland and Durham Universities still had quite high levels of RDA 
grants through until the announcement of the RDA abolition in 2010, but all universities saw their RDA grants drop dramatically in 2011.

Given the economic and political uncertainties, decrease in available resources and increased competitions, universities are likely to be more selective in their key engagement activities within and beyond their city-regions, and be more focused on specific forms of knowledge exchange activities.

\section{Whither the role of HE in the city-regions?}

In Greater Manchester, through the abolition of the RDA, the HE- city-region collaborative mechanisms have been affected. The M:KC struggled over time to reconcile the expectations of the different stakeholders, local-metropolitan tensions, bottom-up visions with national imperatives and to find its place in the changing city-regional development governance architecture in the context of a rationalisation of the economic support infrastructure of the city region, including the newly created Greater Manchester Innovation Group. The CONTACT partnership closed in 2012 with the end of regional collaboration funding that was available under the HEIF. Another form of universities' collaboration in Greater Manchester, the Beacon for Public Engagement between University of Manchester, MMU and University of Salford also ceased its activities in 2012. In Greater Manchester, despite the strengthened city-region governance structure, the pre-existing university collaborative mechanisms have been dismantled, and new strategic relationships under the New Economy and Greater Manchester Innovation Group are still in the making. As a senior academic with an extensive regional engagement experiences in Greater Manchester puts it, while the new city-region structure can be seen as an opportunity, "it takes time for the KE opportunities to develop.” The new localism, and the role of universities in it, is still in the state of flux. 
Among North East universities, despite the long history of the regional association, collaboration began to unwind. The universities agreed to abolish the secretariat for the association and retain the group in name only. The Knowledge House network had already collapsed, soon to be followed by the end of the regional Aim Higher project and there was little on-going regional collaboration left. A new set of vice-chancellors had come onto the scene, each interpreting what was best for their own institution, and without the shared history of collaboration of the early 2000s. At the city-region level, the Newcastle Science Central project with Newcastle City Council and Newcastle University slowed though as the expected rush of investment capital vanished.

Under the more competitive environment for both private and public funding, without public support for collaboration provided by RDAs and HEFCE, there is a less incentive for universities to collaborate across institutions within and across regions. There is a view expressed by some universities that they were able to manage their own links with industry and the local authorities now - "we do feel less in need of [university] partners". Also, the nature of partnership has changed, with a shift from a rationale for complementary collaboration within a region or a city-region to a desire to seek out alternative alliances with peer institutions. As one PVC put it: "Now the strategy is to form partnerships that can add value to the university's research and educational offer, with the money being 'a secondary consideration””.

Increasingly it is being recognised that not all universities can deliver on all agendas. Arguably, instead universities should "build on their strengths or collaborate with one another to contribute more to the local economy” (IPPR/UUK, 2012; p.4). In reality, such processes are extremely varied and messy.

\section{Discussion}


In this paper, we illustrated the changes in regional governance, higher education policies and changing expectations and pressures for universities to engage and work with local and regional agendas, before and throughout the financial crisis and the following economic downturn. Throughout the 1990s and 2000s, the ‘engaged university’ models were developed driven by policy expectations on the roles of universities to meet regional needs (Uyarra, 2010). Regional collaborative mechanisms were promoted through public initiatives in the two case study regions, universities learned to play different roles, and complementarities of institutions were emerging through 'regional systems of innovation'. However, the collaborative relationships were also in part the consequence of new 'regionalism' under the New Labour government, and supported by a number of funding incentives. The expectations around the universities' external engagement under new regionalism were though based on an underestimation of the tensions and contradictions between the different roles, activities and different dimensions of engagement (Stachowiak, 2013).

Such a regional model was gradually being overtaken by a new 'localism' - institutional partnership and governance models embedded in city-regions. However the political and institutional vacuum and fragmentation created by the change in spatial governance structure has created practical issues such as management of EU funds. This scalar shift coincided with the financial crisis and subsequent austerity measures, cuts in public funding and the changes in the higher education funding mechanisms. The drastic reduction of funding and supporting structures devoted to HEIs regional engagement and additional pressures placed upon universities have further brought institutional differences into sharp focus.

Universities’ strategies and behaviours have been shaped by national policy agendas and funding mechanisms as have been observed throughout 1990s and 2000s. Under the new governance structures emerging during the 2010s, whilst universities have been enrolled in 
the new city-region strategic alignment, it has become clear that different types of institutions are forming and implementing different strategies. This implies a change in the character of the ‘engaged university’ model. Regional level collaboration, meeting regional needs and demand has declined in terms of universities’ institutional priority and strategies. Policy infrastructure, resources and funding incentives at the regional level are no longer there, replaced by the city-region/local level partnerships. In both the North East and North West regions, universities are increasingly finding little incentive to collaborate with each other at the regional level. Tensions between the regional and the city-regional levels have always been more prominent in the North West region, where Greater Manchester city-region had always had strong political identity. Even in the North East, where the regional HE collaborative mechanisms had existed over the last three decades, the new local partnership model with LEPs seems to be overtaking the regional collaboration model. Both Newcastle and Greater Manchester have had pilot experiences under Science Cities since the early 2000s, and Greater Manchester has had longer experience of local partnership models at the city-region level. The recent shift to LEPs could lead to a more focused and strategic alignment between universities and city regions - however, both in Greater Manchester and in Newcastle, the new alignment seems to be still in a state of flux.

These changes - new student tuition fees, changes in European funding, research impact agenda, relationships with business, industry and public organisations, as well as the new localism agenda are affecting different dimensions of activities of universities. New challenges emerge at different levels, local, regional national, European, and international levels, and new pressures grow as different agendas intertwine. There are varieties of new pressures and new challenges depending on the types of institutions. Universities, then, are left with the challenge to identify what combination of "institutional policies" will increase 
the volume and speed of flow of knowledge from universities to knowledge users that leads to higher rates of innovation and economic development, meets the needs of policy, practice civil society communities and contributes to open knowledge and free enquiry (Goldstein, 2010). Furthermore, the ways in which universities are able to anticipate the changes are also different - some institutions are able to influence the policy agendas, shape events, and adapt to these changes more than others. The interpretation and implementation of engagement policies and strategies are influenced and conditioned by the institutional values and culture of individual universities - missions, strategies, resources and the nature of the institution's business (Kenney and Goe, 2004; Jongbloed and Zomer, 2010; Vorley and Nelles, 2008) as well as individual academics’ experiences, motivation and perceptions of opportunities as well as barriers related to their work environment.

These two case studies show how universities are part of the new city-region alignment and new strategic leadership roles are expected - however, under post-crisis austerity, changing funding mechanisms and more pressure to compete, universities find it difficult to meet these new expectations, while institutions find themselves in a far more competitive environment with less incentive to collaborate across institutions within the city-region framework. Finally, it is important to be aware that political and economic uncertainties are affecting not only the university but its partners and potential clients.

\section{Acknowledgements}

The authors are grateful to the editors and to two anonymous reviewers for helpful and insightful comments on an earlier draft of this paper. This research draws upon information collected through a number of funded projects over several years including the 'Building 
Science Regions’ project (RES-151-25-0037) funded by the UK Economic and Social Research Council's Science in Society programme, and the Universities and Community Engagement project (RES-171-25-0028) funded by ESRC's programme on the 'Impact of HEIs on regional economies'. The project also drew on work for HEFCE on the Regional Mission of HE (2001), for OECD on 'Supporting the contribution of higher education institutions to regional development' (2005), an evaluation of the ERDF in North East England for the European Commission (2012), and financial assistance from the University of Manchester . 


\section{References}

Abreu, M. and Grinevich, V. (2013) Academic entrepreneurship and the geography of university knowledge flows in the UK, in: Crescenzi, R., Percoco, M. (Eds.), Geography, Institutions and Regional Economic Performance, Advances in Spatial Science. Heidelberg: Springer Berlin, 187-206.

American Association of State Colleges and Universities (2002) Stepping Forward as Stewards of Place, Washington DC:AASCU.

Arbo, P and Benneworth, P (2006) Understanding the regional contribution of higher education institutions, Paris: OECD.

Benneworth, P. (2013) University Engagement with Socially Excluded Communities, Dordrecht: Springer.

Benneworth, P., Charles, D.R. Madanipour, A. (2010) Building localised interactions between universities and cities through university spatial development. European Planning Studies, 18: 16111629.

Bentley, G., and Pugalis, L. (2012) New directions in economic development: Localist policy discourses and the Localism Act. Local Economy, 28: 257-274.

Bentley, G., Bailey, D., Shutt, J. (2010) From RDAs to LEPs: A New Localism? Case examples of West Midlands and Yorkshire. Local Economy, 25: 535-557.

Boucher, G., Conway, C., Van Der Meer, E. (2003) Tiers of engagement by universities in their region's development. Regional Studies, 37: 887-897.

Boudreau, J.-A. (2003) The politics of territorialization: regionalism, localism and other isms ... The case of Montreal. Journal of Urban Affairs, 25: 179-199

Breznitz, S.M. and Feldman, M.P. (2012) The engaged university. The Journal of Technology Transfer, 37: 139-157. 
Briggs, D. (2013) Spheres of Influence: A Reflection on the Achievements and Value Added of North West Universities Association 1999 to 2012. Manchester: NWUA.

Browne, J. (2010) Securing a Sustainable Future for Higher Education: An Independent Review of Higher Education Funding and Student Finance (Browne Report). Available online at: https://www.gov.uk/government/uploads/system/uploads/attachment_data/file/31999/10-1208securing-sustainable-higher-education-browne-report.pdf [Accessed 28 October 2013]

Charles, D.R. (2003) Universities and territorial development: reshaping the regional role of English universities. Local Economy, 18: 7-20.

Charles, D.R. (2006) Universities as key knowledge infrastructures in regional innovation systems. Innovation: The European Journal of Social Science Research, 19: 117-130.

Charles, D.R. (2008) 'From regional innovation strategies to the multi-level governance of science, technology and innovation: the case of the North East of England', in Carayannis, E.G., Assimakopoulos, D. and Kondo, M., Innovation Networks and Knowledge Clusters, Basingstoke: Palgrave Press, 166-185.

Charles, D.R. (2011) The role of universities in building knowledge cities in Australia. Built Environment, 37: 281-298.

Charles, D.R. and Benneworth, P. (2001) The Regional Mission: The Regional Contribution of Higher Education: National Report. London: Universities UK.

Charles, D.R. and Wray, F. (2010) Science cities in the UK, paper presented at Melbourne 2010 Knowledge Cities World Summit, Melbourne, 16th-19th November.

Chatterton, P., Goddard, J. (2000) The Response of Higher Education Institutions to Regional Needs. European Journal of Education, 35, 475-496. 
CONTACT, 2008. Universities Collaborative Third Stream Programme in support of Manchester: Knowledge Capital 2004-2007. Manchester: CONTACT Partnership.

Dawley, S., Marshall, N., Pike, A., Pollard, J, Tomaney, J (2012) Continuity and evolution in an old industrial region: the labour market dynamics of the rise and fall of Northern Rock. Regional Studies, advance copy available on-line, http://www.tandfonline.com/doi/pdf/10.1080/00343404.2012.669473.

Deas, I., Ward, K. (2002) Metropolitan manoeuvres, in: Peck, J., Ward, K. (Eds.), City of Revolution: Restructuring Manchester. Manchester: Manchester University Press.

Department for Business, Innovation and Skills (2013) Sir Andrew Witty’s independent review of universities and growth: preliminary findings. Available online at: https://www.gov.uk/government/consultations/universities-and-growth-the-witty-review-call-forevidence [accessed 30August 2013]

Department for Business, Innovation and Skills (2010) Local growth: realising every place's potential White Paper (Cm 7961). London: The Stationery Office.

Department for Education and Skills (2003) The White Paper on the Future of Higher Education. London: Department for Education and Skills.

DiMaggio P. J. \& Powell, W. (1983) The iron cage revisited" institutional isomorphism and collective rationality in organizational fields. American Sociological Review, 48: 147-160.

Etherington, D., Jones, M. (2009) City-regions: new geographies of uneven development and inequality. Regional Studies, 43: 247-265.

Geuna, A. and Muscio, A. (2008) The governance of university knowledge transfer, SPRU Electronic Working Paper Series No 173, Brighton: University of Sussex.

Glasson, J. (2003) The widening local and regional development impacts of the modern universities a tale of two cities. Local Economy, 1: 21-37. 
Goddard, J., and Chatterton, P. (1999) Regional Development Agencies and the knowledge economy: harnessing the potential of universities. Environment and Planning C: Government and Policy, 17: 685-699.

Goddard, J. and Vallance, P. (2013) The University and the City. Abingdon: Routledge.

Goddard, J., Robertson, D. and Vallance, P. (2012) Universities, technology and innovation centres and regional development: the case of the North East of England. Cambridge Journal of Economics, 36: 609-627.

Goldstein, H. (2010) To what extent is academic entrepreneurship taken for granted within research universities? Higher Education Policy, 23: 1-16.

Gunasekara, C. (2006) The generative and developmental roles of universities in regional innovation systems. Science and Public Policy, 33: 137-150.

Hall, P.(2009) Looking backward, looking forward: the city region of the mid-21st century. Regional Studies, 43: 803-817.

Hewitt-Dundas, N. (2012) Research intensity and knowledge transfer activity in UK universities. Research Policy, 41: 262-275.

Higher Education Funding Council for England (HEFCE) (2011) Funding for knowledge exchange Higher Education Innovation Funding (HEIF) Knowledge exchange funding for 2011 to 2015. Available online at: http://www.hefce.ac.uk/whatwedo/kes/heif/ [Accessed 3 October 2013]. Higher Education Funding Council for England (HEFCE) (2012) Regional Profiles of Higher Education 2009/10. Available online at: http://www.hefce.ac.uk/pubs/year/2012/201207/\#d.en.69527 [Accessed 3 October 2013].

Higher Education Statistics Agency (HESA) (2013) HE Business and Community Interaction Survey 2003-4 to 2011-12. Available online at: http://www.hesa.ac.uk/content/view/2875/393/ [Accessed 23 May 2013]. 
HM Treasury, Department of Trade and Industry and Department for Education and Skills (2004) Science and Innovation Investment Framework 2004-2014. London: HMSO.

Huggins, R., Johnston, A., Stride, C. (2012) Knowledge networks and universities: locational and organisational aspects of knowledge transfer interactions. Entrepreneurship and Regional Development, 24: 475-502

Hughes, A. (2011) Open innovation, the Haldane principle and the new production of knowledge: science policy and university-industry links in the UK after the financial crisis. Prometheus, 29: 411442.

Hutton, W. and Lee, N. (2012) The City and the cities: ownership, finance and the geography of recovery. Cambridge Journal of Regions, Economy and Society, 5: 325-337.

IPPR/UUK (2012) Beyond bricks and mortar boards: universities and the future of regional economic development. Newcastle upon Tyne: IPPR North.

Jongbloed, B and Zomer, A. (2010) Valorisation, knowledge transfer and IP: creating value from academic knowledge, in P. Temple (ed.) Universities in the Knowledge Economy: Higher Education Organisation and Global Change. London: Routledge, 82-102.

Kenney, M. and Goe, W.R. (2004) The role of embeddedness in professional entrepreneurship: a comparison of electrical engineering and computer science at UC Berkeley and Stanford. Research Policy, 33: 691-707.

Kitagawa, F. (2004) Universities and regional advantage: higher education and innovation policies in English regions. European Planning Studies, 12: 835-852.

Kitagawa, F. (2012) City-regions, Innovation and Universities: the Evolution and Transition of the UK Urban Governance Institutions, in Cooke, P (ed.) Reframing Regional Development: Evolution, Innovation \& Transition, Abingdon: Routledge. 
Kitson M., Howells J., Braham R. Westlake S. (2009) The Connected University: Driving Recovery and Growth in the UK Economy. London: NESTA.

Lambert, R., 2003. Lambert Review of Business-University Collaboration. London: HM Treasury. Lawton Smith H. (2007) Universities, innovation, and territorial development: A review of the evidence. Environment and Planning C: Government and Policy 25: 98-114.

Little, B. and Williams, R. (2009) Higher education policy initiatives and their implementation - the case of Lifelong Learning Networks in England. Journal of Access Policy and Practice, 6: 97-115. M:KC (2003) Manchester: Knowledge Capital A place for inspiration, A world of opportunities. Manchester: M:KC.

Marginson, S. (2004) Competition and Markets in Higher Education: a 'glonacal' analysis. Policy Futures in Education, 2: 175-244.

Martin, B. (2012) Are universities and university research under threat? Towards an evolutionary model of university speciation, Cambridge Journal of Economics, 36: 543-565.

Mowery, D., Sampat, B.N. (2005) Universities in national innovation systems, in: Jan Fagerberg, J., Mowery, D.C. and Nelson, R.R. (eds.), The Oxford Handbook of Innovation. Oxford: Oxford University Press.

National Committee of Inquiry into Higher Education (1997) Higher Education in the Learning Society (Dearing Report). Available online at http://www.leeds.ac.uk/educol/ncihe/ [Accessed 28/10/2013].

Newcastle Journal (2011) Blast at North East's 'civil war' over LEP decision, Journal, 20 Sep, available online at: http://www.thejournal.co.uk/news/north-east-news/blast-north-easts-civil-war4423879 [Accessed 28 October 2013]. 
NWUA (2010) The Higher Education Sector in the North West. Fighting recession and supporting recovery. North West University Association.

OECD (1999), The Response of Higher Education Institutions to Regional Needs. Paris: OECD. OECD (2007) Higher Education and Regions: Globally Competitive, Locally Engaged. Paris: OECD. OECD (2008) Reviews of Regional Innovation: North of England, UK. Paris: OECD.

Perkmann, M., King, Z., Pavelin, S. (2011) Engaging excellence? Effects of faculty quality on university engagement with industry. Research Policy, 40: 539-552.

Perry, B. (2011) Universities and cities: governance, institutions and mediation. Built Environment, 37: 245-259.

Perry, B. (2007) The multi-level governance of science policy in England. Regional Studies, 41: 1051-1067.

Perry, B. (2008) Academic knowledge and urban development: theory, policy, and practice, in: Yigitcanlar, T., Velibeyoglu, K., Baum, S. (Eds.), Knowledge-Based Urban Development: Planning and Applications in the Information Era. London: Information Science Reference.

Potts, G. (1998) The HESIN Knowledge House: a front door to North East universities. Local Economy, 13: 267-271.

Power, D., Malmberg, A. (2008) The contribution of universities to innovation and economic development: in what sense a regional problem? Cambridge Journal of Regions, Economy and Society, 1: 233-245

Rose, M., Decter, M., Robinson, S., Jack, S., Lockett, N. (2013) Opportunities, contradictions and attitudes: The evolution of university-business engagement since 1960. Business History, 55: 259279. 
Sainsbury, D. (2007) Speech by Lord Sainsbury, Science Cities Event, Manchester. Department of Trade and Industry. Available online at:

http://webarchive.nationalarchives.gov.uk/+/http://www.dti.gov.uk/about/dti-ministerialteam/page29445.html [Accessed18 May 2013].

Scott, P. (2010) Structural changes in higher education: the case of the United Kingdom, in Palfreyman, D. \& Tapper, T. (eds.) Structuring Mass Higher Education: The Role of Elite Institutions New York: Routledge.

Shaw, K. and Robinson, F. (2012) From 'regionalism' to 'localism': Opportunities and challenges for North East England. Local Economy, 27: 232-250.

Stachowiak, K., Pinheiro, R., Sedini, C., Vaattovaara, M. (2013) Policies aimed at strengthening ties between universities and cities, in: Musterd, S., Kovács, Z. (Eds.), Place-making and Policies for Competitive Cities. John Wiley \& Sons, 264-290.

Trippl, M., Sinozic, T., Lawton Smith, H. (2012) The "third mission” of universities and the region: comparing the UK, Sweden and Austria. Presented at the 52nd European Congress of the RSAI, 2125 August 2012, Bratislava, Slovakia. Available online at: http://wwwsre.wu.ac.at/ersa/ersaconfs/ersa12/e120821aFinal00063.pdf [Accessed 28 October 2013].

Turok, I. (2009) The distinctive city: pitfalls in the pursuit of differential advantage. Environment and Planning A, 41: 13-30.

Universities UK (2008) Devolution and Higher Education: Impact and Future Trends, London: Universities UK.

University of Sunderland (2012) HEIF 2011-15 institutional strategy. Available online downloaded from http://www.hefce.ac.uk/whatwedo/kes/heif/ [Accessed 3 October 2013].

Uyarra, E, (2010) Conceptualizing the regional roles of universities, implications and contradictions. European Planning Studies, 18: 1227-1246. 
Uyarra, E. and Flanagan, K. (2010) From regional systems of innovation to regions as innovation policy spaces. Environment and Planning C, 28: 681-695.

Vorley, T., and Nelles, J. (2008) (Re)conceptualising the third mission: entrepreneurial architecture of higher education institutions. Policy Futures in Education, 7: 284-296.

Warren, L., Kitagawa, F., Eatough, M. (2010) Developing the knowledge economy through university linkages: an exploration of RDA strategies through case studies of two English regions. International Journal of Entrepreneurship and Innovation, 11: 293-306.

Watson, D, Hollister, R., Stroud, S., E., and Babcock, E (2013) The Engaged University: International Perspective on Civic Engagement. New York: Routledge.

Williams, L. Turner, N., Jones A. (2008) Embedding Universities in Knowledge Cities London: Work Foundation. Available online at:

http://www.theworkfoundation.com/assets/docs/publications/208_ideopolis_education061208.pdf [Accessed 28 October 2013]. 
Table 1. Characteristics of the case study regions and their universities.

\begin{tabular}{|l|l|l|}
\hline Region & North East & North West \\
\hline Population (2011) England 53.107m & $2.596 \mathrm{~m}$ & $7.056 \mathrm{~m}$ \\
\hline Unemployment rate (Q4 2012) England 7.7 & 9.7 & 8.5 \\
\hline GVA per head (2011) England f21,349 & $£ 15,842$ & $£ 17,754$ \\
\hline Total jobs (end 2012) & $1.160 \mathrm{~m}$ & $3.442 \mathrm{~m}$ \\
\hline Manufacturing jobs & & $0.352 \mathrm{~m}$ \\
\hline Universities & $0.115 \mathrm{~m}$ & 12 \\
\hline HEl registered and taught students (2009-10) & 102,645 & $245,185^{1}$ \\
\hline Main city-region and population (metro county & Newcastle, 1.65m & Manchester, \\
\hline
\end{tabular}

Source: ONS Region and County Profiles key statistics 2012, ONS Regional Labour Market Statistics 2012; HEFCE regional profiles 2012.

Note: HE student numbers include a small campus of the University of Huddersfield and two small performing arts colleges not counted in the number of universities

1 
Table 2. The area identified as being of greatest priority in a university's institutional mission

\begin{tabular}{|l|l|l|l|}
\hline & $\mathbf{2 0 0 7}$ & $\mathbf{2 0 0 9}$ & $\mathbf{2 0 1 1}$ \\
\hline University of Bolton & RDA area & RDA area & RDA area \\
\hline Manchester Metropolitan & RDA area & RDA area & RDA area \\
\hline Northumbria University & RDA area & RDA area & Area defined by the \\
& Area defined by & Area defined by & Area defined by the \\
thiversity of Sunderland & the HEI & HEI \\
\hline University of Durham & RDA area & Area defined by & Area defined by the \\
the HEI & HEI \\
\hline University of Newcastle & RDA area & RDA area & Area defined by the \\
& & HEI \\
\hline University of Salford & RDA area & RDA area & RDA area \\
\hline University of Manchester & Locality-city or & Area defined by & Area defined by the \\
town & the HEI & HEI \\
\hline
\end{tabular}

Source: HESA (2013). 


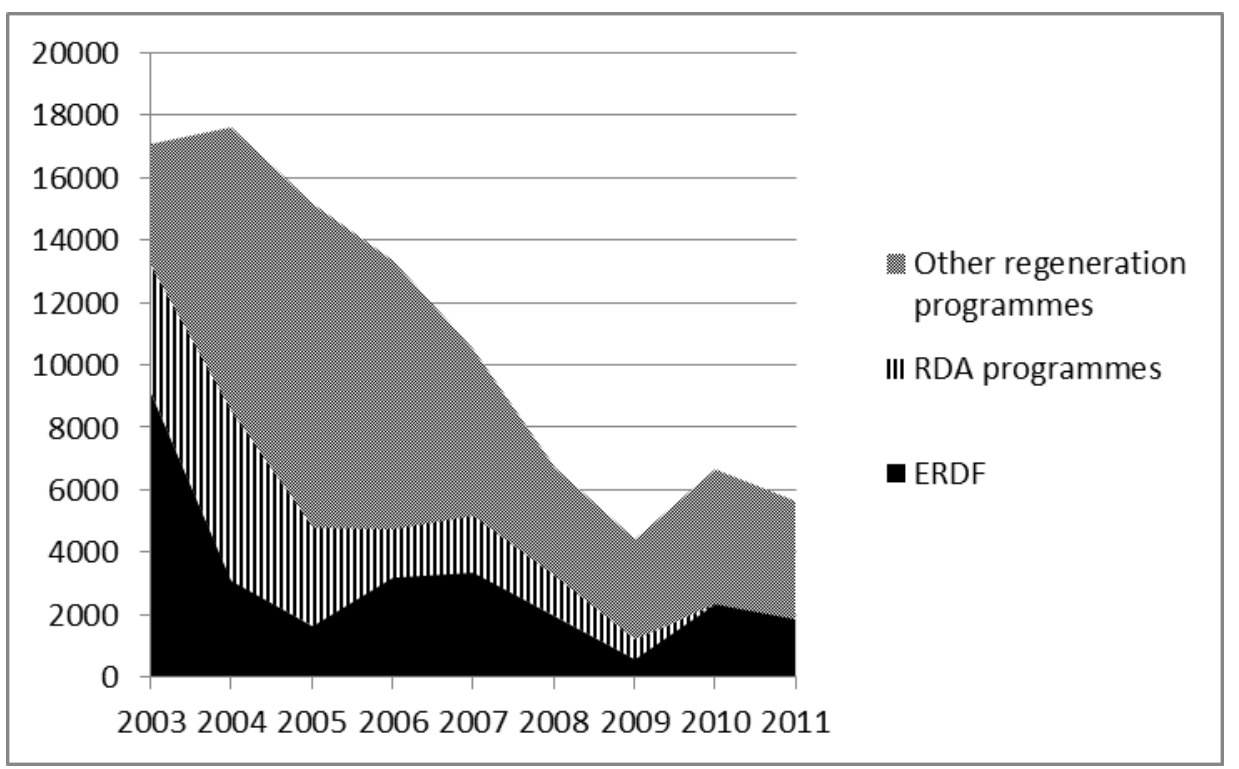

Figure 1: Income from regeneration policy sources for Manchester universities (£’000s inflation adjusted to 2011)

Source: HESA (2013) 


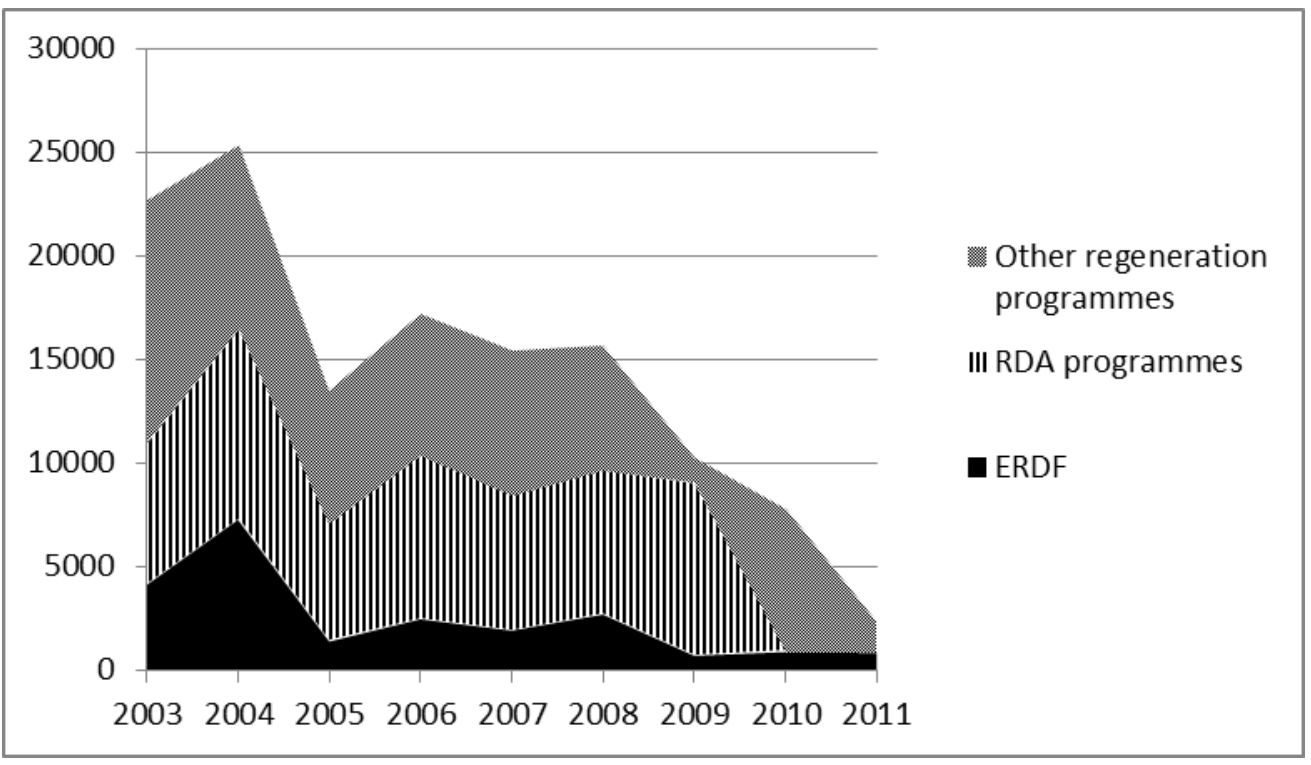

Figure 2: Income from regeneration policy sources for Newcastle universities ( $£^{\prime} 000$ s inflation adjusted to 2011)

Source: HESA (2013) 


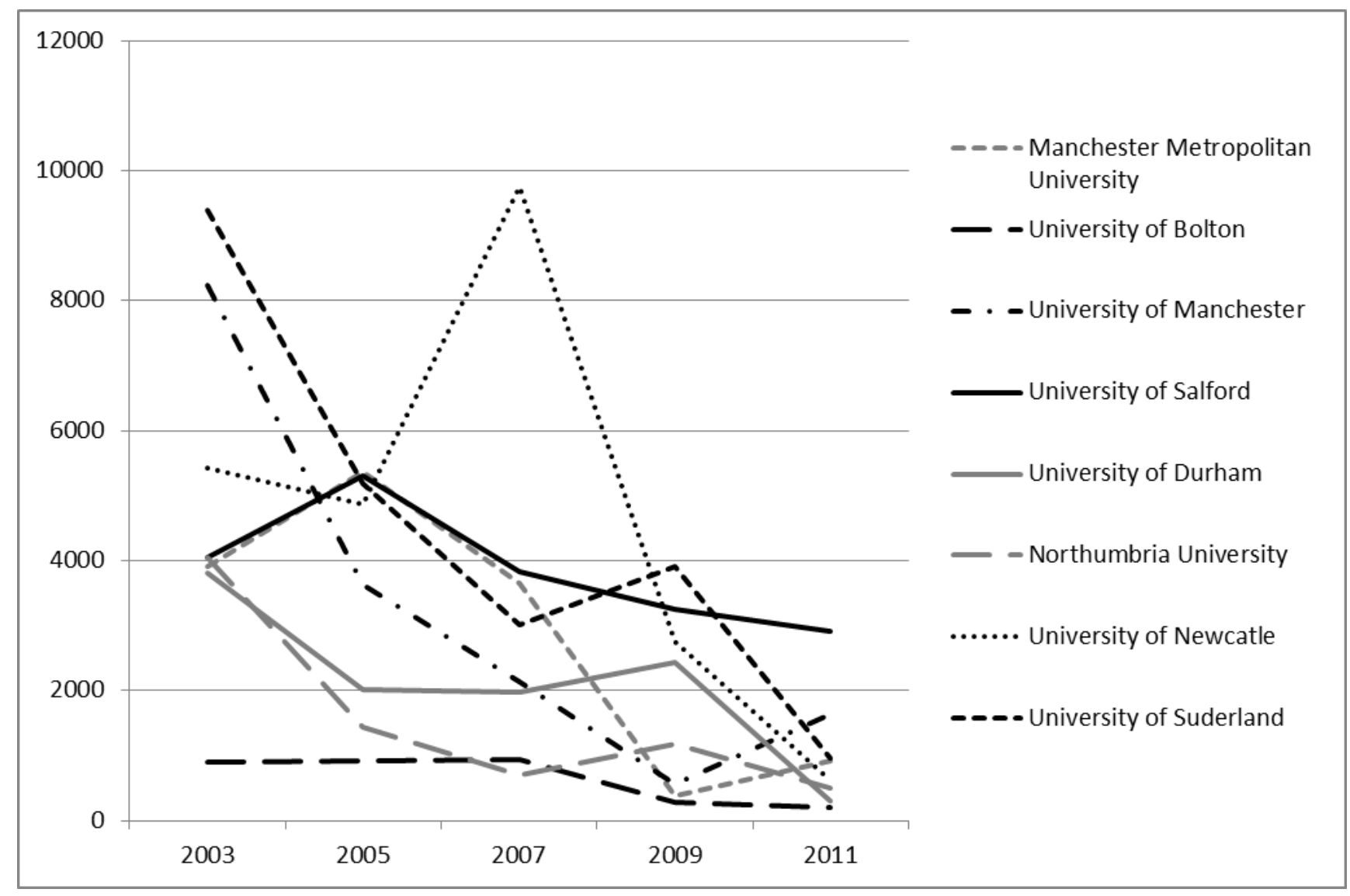

Figure 3: Total regeneration income for eight city-region universities (£000s inflation adjusted to 2011)

Source: HESA (2013) 


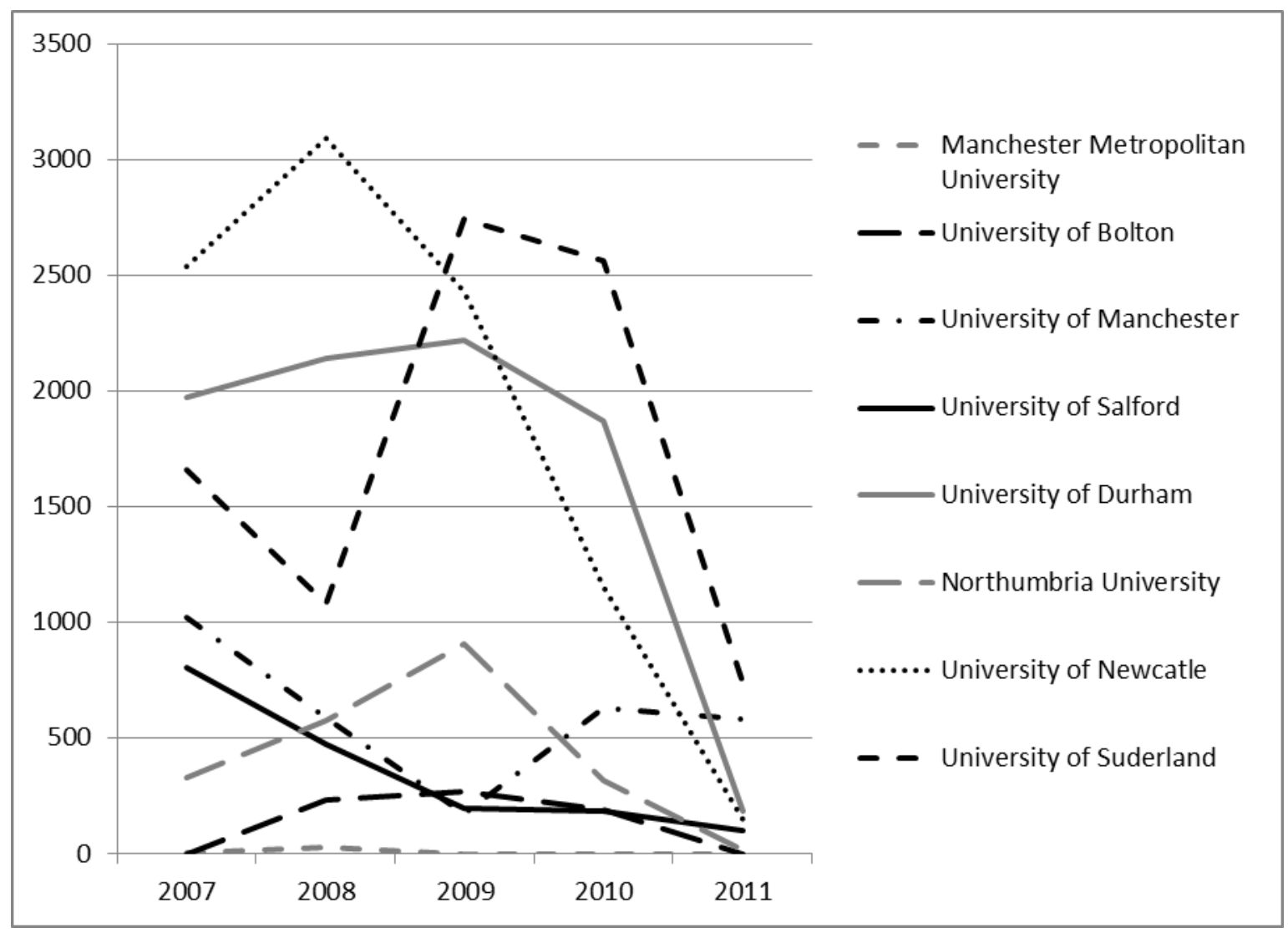

Figure 4: Regeneration revenues from RDAs for the eight city-region universities 2007-2011 (£000s inflation adjusted to 2011)

Source: HESA (2013)

\footnotetext{
' http://www.n8research.org.uk/about-us/success-to-date [accessed 30/08/13]

ii The interviews in the North East region were primarily associated with a study on the ERDF in the region but with a major focus on the evolution of regional partnerships.

iii European Regional Development Fund and European Social Fund
} 